日本の近代麻酔の夜明けと麻酔科医の社会的地位

\title{
派遣麻酔と麻酔科医の社会的地位：現状と今後の展望
}

[要旨］少子·超高齢社会を迎えるわが国は, 社会保障の持続可能性を高めていかなければならない. そのためには, 医療側においても, プロフェッショナルオートノミーの下, 公立・公的病院と民間 病院の役割分担, かかりつけ医機能の推進, 医療費の適正化, 健康寿命の延伸策等の改革を推進し ていく必要がある. そうした状況下, 麻酔科医にも高度な自律性がより求められている. いわゆる 「派遣麻酔」の紹介料等の源泉は社会保障財源である. 学会による取り組みも進められているが, 国民や医療界からの信頼の確保と持続可能な社会保障の実現のためには, 麻酔科医自身が自浄能力 を持つことが重要であり, それが麻酔科医の社会的地位の向上の必要条件である.

キーワード : 持続可能な社会保障, 麻酔科医, フリーランス, 派遣麻酔, プロフェッショナルオー トノミー

I わが国の社会保障と

医師のプロフェッショナルオートノミー

2025 年は, 全ての団塊世代が 75 歳以上となる年 であり，2040年は，団塊ジュニア世代が 65 歳以上 となり, 高齢者数, 年間死亡者数がピークを迎える 年である。内閣官房・内閣府・財務省・厚生労働省 が2018年 5 月 21 日に取りまとめた「2040年を見据 えた社会保障の将来見通し(議論の素材)」によれば, 社会保障給付費の対GDP 比は，2018年度の $21.5 \%$ (名目額121.3兆円) から，2025年度に $21.7 \sim 21.8 \%$ (同 $140.2 \sim 140.6$ 兆円) となり，その後 15 年間で 2.1 〜 2.2\%ポイント上昇し，2040年度には $23.8 〜 24.0$ $\%$ (同 $188.2 \sim 190.0$ 兆円) となる (計画ベース) と推計 されている(図1).

わが国は，2025年，2040年に向け，社会保障の
持続可能性を高めていかなければならない。そのた めには，医療界においても，プロフェッショナルオ 一トノミーの下，入院医療機能の分化，公立・公的 病院と民間病院の役割分担, 人生の最終段階の医療, 高額薬剤の適正使用，かかりつけ医機能の推進，医 療費の適正化，健康寿命の延伸策等の改革を推進し ていく必要がある(図2)。

また，医師の㗢き方改革としてタスクシフティン グ等が謳われているが，それらは，あくまでも医療 安全や医療への信頼の観点で適切に進められるべき ものである。

\section{II 「派遣麻酔」の課題}

そうした状況下，麻酔科医にも高度な自律性がよ り求められている。例えば全身麻酔手術については, 一部の大病院への集約や地域差も見られるが，これ

著者連絡先 今村 聡

干 113-8621 東京都文京区本駒込2-28-16 日本医師会地域医療課 


\section{社会保障給付費の見通し（経済：ベースラインケース）}

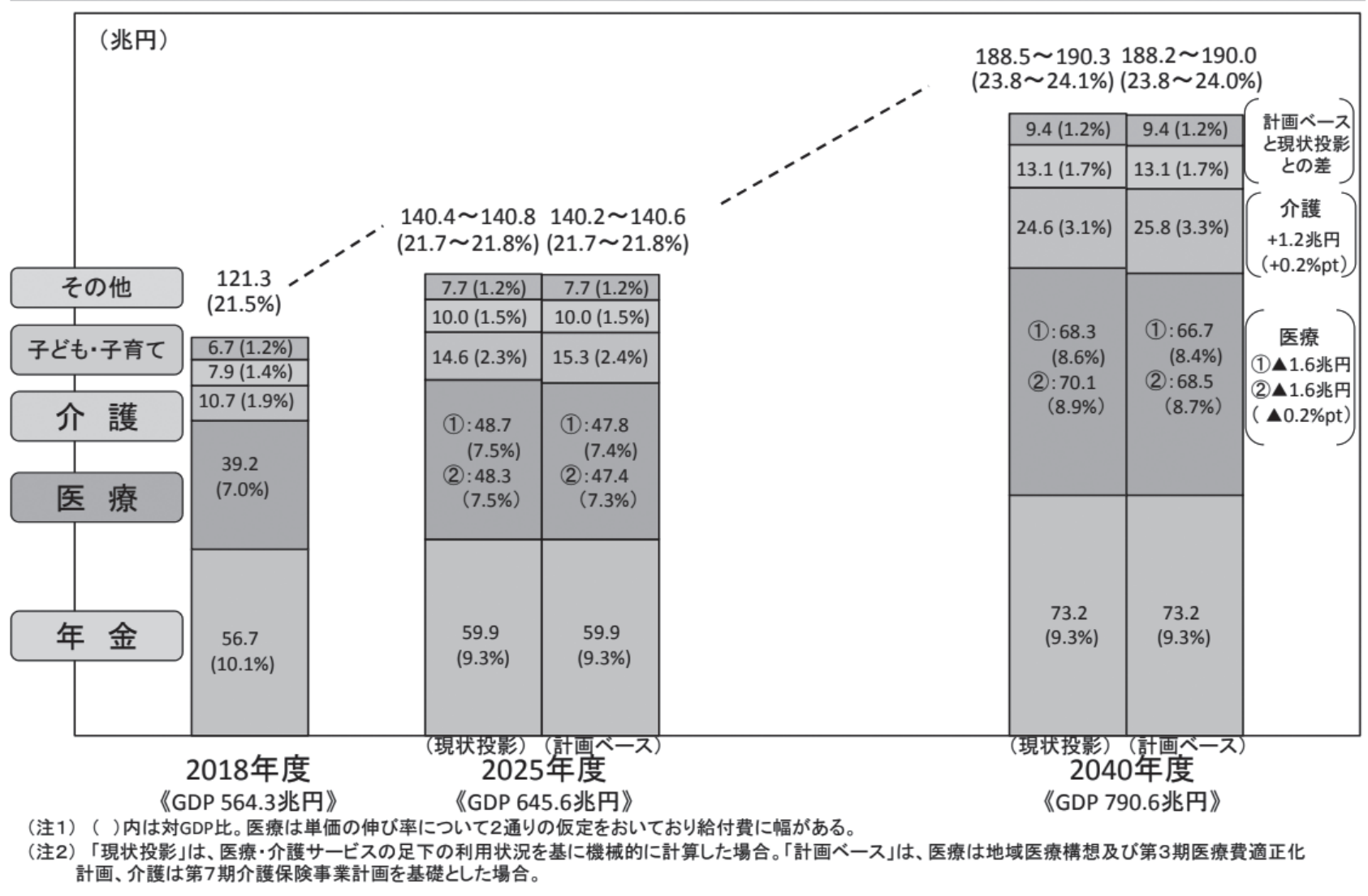

図 1 社会保障給付費の見通し

〔内閣官房・内閣府・財務省・厚生労働省：2040年を見据えた社会保障の将来見通し(議論の素材)。2018年5月 21 日よ り引用了

からの医療提供体制において麻酔科医の重要性は高 まっていく。しかし，フリーランスの医師による， いわゆる「派遣麻酔」が行き過ぎれば，麻酔科医自 身の信頼低下にもつながる.

「派遣麻酔」の紹介料等のほとんどは公的保険の 保険料や税を財源とする。厚生労働省「医療従事者 の需給に関する検討会 医師需給分科会」中間取り まとめ(2016年 6 月)では，麻酔科医に限るわけでは ないが，「医師の資格や専門性が有する公益性を踏 まえ，いわゆるフリーランス医師や多額の紹介料・ 給料を要する者への対応について検討する」ことを 医師偏在対策の一つとした(図3).

こうした問題意識は，職業紹介事業を所管する職
業安定法の改正にもつながっている，日本医師会に おいても，医師や看護師を紹介する一部の人材職業 紹介事業者に見られた，早期退職時の返戻のない高 額手数料や転職の助長等，不適切な行為に対し，公 の検討の場等で是正を要求してきた。

2018年1月に施行された改正法は，6か月以内の 離職者の管理，自らの紹介による就職者への転職勧 奨の禁止 ( 2 年間), 返戻金制度の設置(努力義務)等, 事業者に規律を求める内容である。

医療界における取り組みとしては，まず，2018 年度診療報酬改定における評価の見直しが挙げられ る。改定を論議した中医協の場に，日本麻酔科学会 による「麻酔科医のマンパワーに関する調査」(2015 


\section{入院医療}

\begin{tabular}{l}
\hline 機能分化 \\
$>$ 患者の病期(高度急性期、急性期、回復期、慢性期)に応じた病床の機能分化 \\
$>$ 地域に密着した中小病院と大病院の機能分化 \\
\hline 公立病院、公的医療機関等の非稼働病床の削減 \\
\hline 人生の最終段階の医療 \\
\hline 高額薬剂の適正使用 \\
\hline 手術の際の医療材料の適切な選択 \\
\hline 外 来 医 療 \\
\hline かかりつけ医による適切な受療行動等、地域包括ヶアの推進 \\
\hline 症状や患者特性に応じてコスト意識を持った処方 \\
\hline 日本健康会議による医療者、企業、保険者の取り組み \\
\hline かかりつけ医による生活習慣病・ロコモ対策 \\
\hline 長期処方の是正 \\
\hline
\end{tabular}

\section{医療側からの改革の推進}

>地域医療構想に基づく地域医療 介護総合確保基金で対応

$>$ 大病院選定療養などによる国民 への啓発

新公立病院改革プラン、公的医療 機関等2025プランの着実な実行

尊厳ある終末期についてACP等の 国民への啓発

効果の有無をふまえた投薬

年齢や機能に応じた観点を勘案

かかりつけ医機能研修制度

診療ガイドライン等への掲載

経済界、医療関係団体、自治体の リーダーが協力し、好事例を横展開

健康寿命の延伸

かかりつけ医による服薬管理

図2 持続可能な社会保障のための提言と解決策の例

医療界による取り組み

年1月9日)の結果が提出され，外部からの麻酔科 医の定期的な要請の状況と報酬額 (一般病院, 大学 病院別), その医師の要請先, さらに, 外部から要 請する場合の課題として，「麻酔科医への謝金・給 与が他科に比べて高い」との回答が「要請しても常 に来てもらえるとは限らない」と同程度であること も示された。

そのような経緯をも踏まえ，2018年度改定にお ける麻酔科の診療に係る評価では，「麻酔科におい ては，外部から派遣される医師の活用が進んでいる 一方で，その課題も指摘されている.」として，常 勤の麻酔科医による総合的な医学管理及び長時間の 閉鎖循環式全身麻酔をより重視するよう見直しがな された。

さらに，日本麻酔科学会では，2019年度からの 日本専門医機構による麻酔科専門医更新認定の開始 に向け，麻酔科専門医更新要件に「単一施設に週 3
日勤務すること」の追加を決めた。申請時点で単一 の医育機関病院や病院施設に週 3 日以上勤務し，麻 酔科関連業務に専従していることが要求される.

2018年7月 10 日付同学会会員宛通知により, 麻 酔管理の質を高める観点から常勤の麻酔科医による 周術期の総合的な管理をより重視すべきであり，現 在，麻酔科医の勤務形態について，他団体，国会議 員から様々な意見を受けており，早急な対策を講じ る必要もあり，この決定に至ったとの説明がなされ ている。 また，同学会による QAでは，当該要件追 加の経緯として，「同一施設(診療所含む：他の $\mathrm{Q}$ より)で週 3 日以上勤務することにより，他科と連 携して周術期を中心とする総合的な患者管理(術前, 術後の管理)に関わることで麻酔科専門医としての 社会的役割を果たすことが目的」であることが示さ れている他，「出張麻酔のクリニックの開業，医師 派遣会社に登録の場合はどうなるか」との問いに対 
1. 医師の配置に係る対策 (直接的な対策)

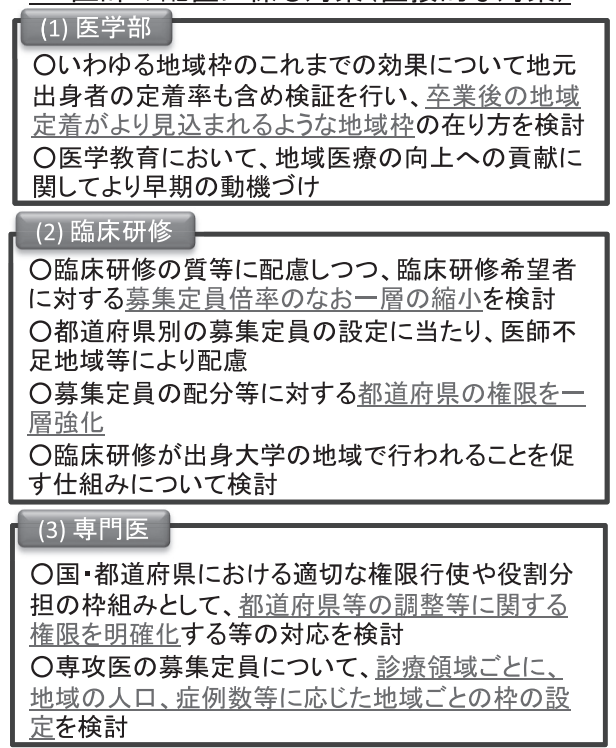

(4) 医療計画による医師確保対策の強化

○医療計画に、医師不足の診療科・地域

等について確保すべき医師数の目標値を

設定し、専門医等の定員の調整に利用

O将来的に医師偏在等が続く場合に、十 分ある診療科の診療所の開設について、 保険医の配置"定数の設定や、自由開業. 自由標榜の見直しを含めて検討

\section{(5) 医師の勤務状況等のデータベース化}

○医籍登録番号、三師調査等の既存の仕 組みの活用も念頭に置きつつ、医師の勤 務状況等を把握するためのデータベース 化について検討

\section{(6) 地域医療支援センターの機能強化}

○地域医療支援センターについて、所在地 の医育機関と連携し、医学部入学から生 涯にわたる医師のキャリア形成·異動を把 握し、キャリア形成支援、配置調整ができ るよう、その機能を強化

\section{(7) 都道府県から国等への対策の求ぬ}

○都道府県が、国、関係機関等に必要な 対策を求めることができる枠組みの検討

\section{(8) 管理者の要件}

○特定地域·診療科で一定期間診療に従 事することを、臨床研修病院、地域医療支 援病院、診療所等の管理者の要件とする ことを検討

\section{(9) フリーランス医師への対応}

○医師の資格や専門性が有する公益性を 踏まえ、いわゆるフリーランス医師や多額 の紹介料·給料を要する者への対応につい て検討

\section{(10) 医療事業の承継税制}

○地域の医療機関の事業の承継に関し、 中小企業と同様、事業承継に当たっての優 遇税制について検討

2. 医師の就労環境改善等に関する対策 (間接的な対策)

\section{(1) 女性医師の支援}

○病院における柔軟な勤務形態 の採用等、妊娠·子育て中の女性 医師の就労継続·復職支援に資 する取組の推進

\section{(2) 技術革新に対応した医療提供}

○医師が業務を効率的に行うこと ができるよう、ICT等の技術革新を 活用した医療提供を推進
(3) チーム医療

○医師が業務を効率的に行い、質 の高い医療を提供できるよう、各医 療スタッフの役割分担を見直し、 チーム医療を推進

\section{(4) サービス受益者に係る対策}

○医療機関の詳しい診療内容や「か かりつけ医」について、住民等への情 報提供を推進

図3 厚生労働省「医療従事者の需給に関する検討会 医師需給分科会」第 1 次中間取りまとめ(平成 28 年 6 月)

しては，「派遣先で同一施設週 3 日以上 麻酔科関 連業務への専従をしていることが，要件を満たす.」 の回答がなされている。

\section{III 麻酔科医に求められるもの}

上記の通り，麻酔科学会を含む医療界を挙げて， 2040年を新たなターゲットイヤーとする改革に取 り組んでいかなければならない状況にある。これは, 麻酔科医をはじめ個々の医師においても同様であ る.

麻酔科医の「派遣麻酔」問題は, 医師の偏在対策, 地域の救急医療や手術の実施にも深刻な影響を与え うる。厚生労働省 医療従事者の需給に関する検討 会 医師需給分科会では，様々な方策を試みても効 果がなかった場合は，規制的な手法を導入すべしと の強い意見が見られ，同分科会取りまとめにも一定 程度反映されている。
医師のプロフェッショナルオートノミーによる偏 在解消ができなければ，国は，医師の開業や専門性 の選択に対して管理を徹底しかねない。医師会や学 会だけではなく，個々の医師の自律が求められてい る.

日本医師会は，2013年 6 月，医師としての高い倫 理観と使命感を礎に，国民の連帯と支え合いに基づ く国民皆保険制度を守ることなどを約束する「日本 医師会綱領」を定めた。

国民や医療界からの信頼の確保と持続可能な社会 保障の実現のためには，麻酔科医自身が自浄能力を 持つことが重要であり, それが麻酔科医の社会的地 位の向上の必要条件である。

同時に, 日本医師会として，フリーランス化の要 因である勤務医の厳しい勤務環境の改善を重要テー マに掲げて取り組んでいく. 


\title{
Social Standing of the Anesthesiologist Dispatch Service and Anesthesiologists : Current Status and Future Prospects
}

\author{
Satoshi IMAMURA \\ Vice-President, Japan Medical Association
}

Japan, faced with a low birth rate and a super-aging society, must improve its social security sustainability. The medical community needs to assist in this effort by promoting various reforms based on professional autonomy, such as role-sharing between public and private hospitals, promotion of the use of primary care physicians ("kakaritsuke physicians"), optimization of the national medical expenditure, and efforts to extend healthy life expectancy.

These efforts call for enhanced professional autonomy among anesthesiologists. The tax withheld on the referral fee for the so-called "anesthesiologist dispatch service" is one source of social security revenue. Various efforts by academic societies are underway to earn and ensure trust from the public and the medical community and to realize sustainable social security, but the key issue here is for anesthesiologists to develop more professional autonomy. Having self-discipline will be an essential requisite for anesthesiologists to improve their own social standing.

Key Words : Sustainable social security, Anesthesiologist, Freelance, Anesthesiologist dispatch service, Professional autonomy

The Journal of Japan Society for Clinical Anesthesia Vol.39 No.5, 2019 